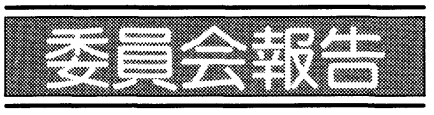

\title{
連続ミキサによる現場練りコンクリート施工指針（案） \\ RECOMMENDED PRACTICE FOR CONCRETE MADE BY CONTINUOUS MIXER
}

\author{
コンクリート現場練り施工指針小委員会
}

By Subcommittee on Recommendations for Mixing Concrete in Site, JSCE

\section{1. まえがき}

連続ミキサは，計量と練りまぜを連続して行える機構 をもつため, 現場練りコンクリートに実用されてきた.

その使用実績を反映して, 昭和 55 年度の土木学会コン クリート標準示方書の部分改訂の際に, 責任技術者の承 認を得ることを条件に使用できるようになったが，施工 の指針が十分でなかったため，実際の使用に支障をきた していた.

土木学会コンクリート委員会は, 昭和 58 年 4 月, 社 団法人日本建設機械化協会の委託に応じて，コンクリ一 卜現場練り施工指針小委員会（委員長：西澤紀昭）を設 置し，指針制定の作業に着手した. その後, 約 3 年にわ たって調査・研究を重ねて, 今年 6 月に「連続ミキサに よる現場練りコンクリート施工指針 (案)」を発刊した. また，指針制定のための調査・研究の結果は，土木学会 コンクリート標準示方書にも取り入れられ，本指針 (案) は標準示方書を補完するものとなっている.

本指針（案）の制定にあたっては，次の事項が配慮さ れた。

(1) 連続ミキサは現在一般に実用されている容積計量 のものを対象とするが，これに限定することはしな い.

(2) 計量の精度はバッチミキサと同等の規定を満足す るものとする.

(3) 連続ミキサ, キャリブレーションなどの用語を明 確にする.

(4) 連続ミキサに特有な機構, 据付けおよび配置計画, 機械管理作業要領, ならびに配合設計から製造まで のフローチャートなどは, 付属資料に揭載して, 使
用の便宜を図る.

本指針 (案) の目次は次のようである. 以下その内容 について説明を加える.

I. 連続ミキサによる現場練りコンクリート 施工指針 (案)

1 章 総則

2 章 コンクリートの品質

3 章 材料

4 章 配合

5 章 連続ミキサの設置

6 章 材料の計量および供給

7 章 練りまぜ

8 章 レデーミクストコンクリート

9 章 特殊な用途

10 章 品質管理および検査

土木学会規準 (案)

1. 連続ミキサの計量・供給性能試験方法

2. 連続ミキサの練りまぜ性能試験方法

II. 付属資料

\section{2. 連続ミキサ}

連続ミキサは「コンクリート材料の計量, 供給および 練りまぜを連続的に行い，フレッシュコンクリートを連 続して製造し, 排出する装置」と定義し, 計量および供 給装置とミキサ部より成り立っている. その性能は連続 ミキサの種類や型式により著しく異なるため, 本指針 (案) と並行して目次に示した土木学会規準 (案) を作 成し，これらに基づいてそれぞれ計量キャリブレーショ ンと練りまぜ性能試験を行って, 性能の確かめられた型 
式のものを用いることにした.

\section{3. 粗骨材の最大寸法}

粗骨材は最大寸法が $40 \mathrm{~mm}$ 以下のものを用いること にした．これは，現在実用されている連続ミキ开の骨材 の供給量は, カットゲートの開き量により調整される機 構となっているのが一般的であり, カットゲートの構造 は $40 \mathrm{~mm}$ 以下の最大寸法の骨材を目標として設計・製 作されている実状に合わせたものである.

\section{4. 材料の計量および供給}

連続ミキサは各材料を連続的に容積計量しているた め,「各材料は, 容積で計量してょい」とした。これら の量を制御するため，ベルトフィーダやパイプ等にそれ ぞれ設けられているカットゲートや調整バルブなどの目 盛りを調整する必要がある. その調整の基本として,「計 量および供給は，一般に単位時間当たりのセメント量を 基準とし，示方配合のコンクリートが得られるように， 骨材，水および混和材料のそれぞれの量を調整する方法 で行う」ことにした。

計量誤差は，バッチミキサと同じにしたが，連続ミキ サでは, バッチミキサのように「1回の計量分量」といっ た規定ができない，そのため，計量誤差の検査に用いる 計量分量は, 所定の時間当たりの計量分量を質量に換算 する方法を採った。そして，「所定の時間当たりの計量 分量は，ミキサの型式，機種，配合などに基づいて，こ れを定めなければならない」と本文に規定し，解説には， 「工事の規模や重要度により異なるが，一般には，コン クリート $0.2 \mathrm{~m}^{3}$ 程度を造るときに用いる材料の計量分 量」としてよいことを示した。

\section{5. キャリブレーション}

メーカ一出獄時 計留キャリブレーション(型式証明)

現 場

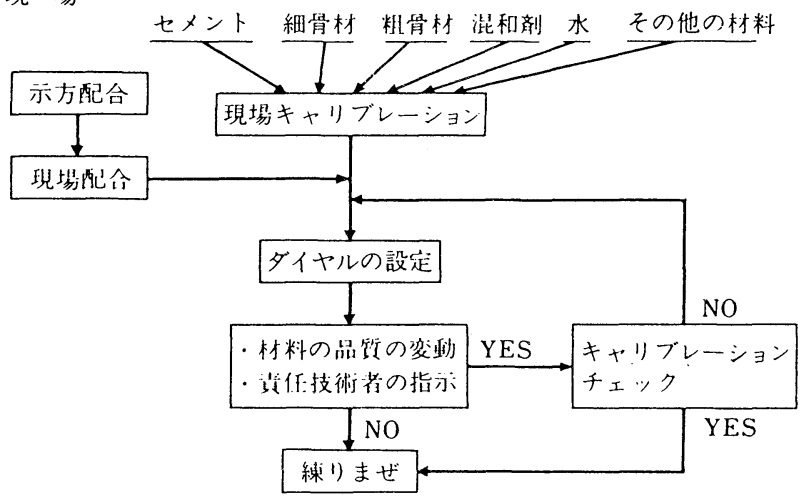

図一1 キャリブレーションのフローチャート
連続ミキサは容積計量のため，各材料の量を制御する ためのカットゲートやバルブなどの開き量を示す目盛り が同一であっても，材料の種類や品質の変動等によって 供給量が変化する。このため，キャリブレーションが必 要となり，その方法は，図一1にフローチャートを示す ように, 計量キャリブレーション,現場キャリブレーショ ンおよびキャリブレーションチェックに分けて行うこと にした。

計量キャリブレーションは「製造メーカーが，連続ミ キサの各型式ごとに，標準的な材料を使用して実動試験 を行い, 材料の容積計量装置の目盛りと所定の時間に供 給される材料の実測質量との関係を求めること」であり， 製造メ一カーはキャリブレーションした結果を連続ミキ サ出荷時に添付するのを原則としている。

現場キャリブレーションは「工事開始前に，現場で使 用する各材料について, 容積計量装置の目盛り之所定の 時間に供給される材料の実測質量との関係を求めるこ 亡」であり，所定の供給量を得るための目盛りの設定が できることを主目的とする.

キャリブレーションチェックは「現場配合に応じて， 現場キャリブレーションの結果に基づき，設定した材料 別の計量装置の目盛りで供給した各材料の質量が, 計量 の許容誤差以下であることを確かめること」である．現 場で使用する材料の品質, 特に骨材の粒度, 含水状態な ごの品質に大きな変動が生じたとき，および責任技術者 が指示する時期に行う.そして, 品質に大きな変動が生 じた場合を明示した。

\section{6. 練りまぜ}

コンクリートの各材料は, 一般に, 樋状のオーガタイ プのミキサ部で練りまぜられる．練りまぜ時間は「ミキ サ部をコンクリート材料が練りまぜられながら通過する 時間」と定義し，「その時間は，10２0秒の範 囲を標準とする」とした。

このタイプのミキサで練りまぜたコンクリー 卜は，排出後数分間における時間経過に伴う品 質の変化が，バッチミキサの場合より一般に大 きいことから，「スランプ試験および空気量試 験は，ミキサから排出後，あらかじめ定めた時 間経過後に行うものとする」と規定した。一般 には, ミキ开から排出後 5 分程度で行うことが 多い.

練りまぜ開始直後，練りまぜ時間に相当する 時間に最初に排出されるコンクリートの品質 は，それ以降に排出されるものに比べて劣って いることから，原則としてそのコンクリートを 廃棄することにした。しかしながら，廃棄でき 
ない場合もあるため，廃棄しなくてもよい対策方法を解 説に示した。なお，「ミキサ部を停止したのち、ミキサ 部内のコンクリートが固まり始めるまでに再び練りまぜ を開始する場合は, コンクリートを廃棄する必要はない」 ことを追記した。

\section{7. 特殊な用途}

特殊なコンクリートの製造および特殊な工法に連続ミ キサを用いる場合における施工上の留意事項について は，24 条特殊な用途の解説に, (1)超速硬コンクリート, (2)鋼瀻維補強コンクリート，(3)吹付けコンクリート，(4) モルタルの製造, (5)その他の特殊な工法として, ソイル セメント, 混和材料の現場における後添加再練り, プレ ミックスモルタル，重量コンクリートなどを取り上げ, それぞれ詳しく述べている。

\section{8. 土木学会規準（案）}

連続ミキサの性能を試験する方法を規定したが，2つ の規準 (案) には, 計量および供給装置の性能ならびに
練りまぜ性能のそれぞれの標準値も示している.これら の試験に合格した型式の連続ミキサを用いることを前提 に，本指針（案）を定めている.

\section{9. 付属資料}

付属資料には，連続ミキサを用いて現場練りコンク リートを製造する場合に必要な，連続ミキ开の機構，据 付けおよび機械管理作業要領といった八ードなものだけ でなく,キャリブレーションのフローチャートとその方 法や実施例，現場配合に基づく各材料の供給量の設定方 法，練りまぜられたコンクリートの品質の特徴などのソ フトなものまでを詳細に示している．また，代表的な既 往の施工例を紹介するとともに，小委員会で実施した連 続ミキサにおける骨材の計量および供給に関する実験, ならびに連続ミキサによるフレッシュコンクリートの品 質をバッチミキサと比較した実験のそれぞれの結果につ いてもとりまとめて，施工の便に供している.

（文責：辻 幸和 $/ 1986.7 .8 \cdot$ 受付） 